\author{
Hermann Wrigge \\ Eduardo L. V. Costa \\ Thilo Busch
}

\section{Adjunctive therapy with inhaled nitric oxide for severe acute chest syndrome in patients with sickle cell disease}

Received: 23 September 2015

Accepted: 25 September 2015

Published online: 2 October 2015

(C) Springer-Verlag Berlin Heidelberg and ESICM 2015

H. Wrigge (®) · T. Busch

Department of Anaesthesiology and Intensive Care Medicine, University of Leipzig, Leipzig, Germany

e-mail: hermann.wrigge@ medizin.uni-leipzig.de

E. L. V. Costa

Cardio-Pulmonary Department, Pulmonary Division, Hospital das Clínicas, Universidade de São Paulo, São Paulo, Brazil

Sickle cell disease (SCD) is a group of monogenetic disorders characterised by haemoglobin S polymerisation, which is promoted by regional tissue hypoxia. Increased erythrocyte rigidity and abnormal interaction with white blood cells, leucocytes, platelets, endothelium, and clotting factors result in recurrent phases of vaso-occlusion, which, often combined with inflammation, can affect different organs. Further, chronic anaemia, haemolysis, and vasculopathy are associated with SCD. Cell-free haemoglobin due to intravascular haemolysis reacts more rapidly with nitric oxide (NO) than does erythrocyte haemoglobin, resulting in a depletion of endogenous NO which is further enhanced by increased arginase synthesis. This functional NO deficiency and oxidative stress due to cycles of ischaemia and reperfusion aggravate the hypercoagulable state of SCD. Repeated vaso-occlusive crises in SCD patients are associated with severe pain and risk of organ damage [1].

The acute chest syndrome (ACS) represents a serious pulmonary complication of SCD. ACS is characterised by pulmonary intravascular sequestration of sickled erythrocytes most commonly triggered by pulmonary infection or embolisation of bone marrow fat. ACS is characterised by sudden onset of fever, wheeze, cough, chest pain, shortness of breath, and new pulmonary infiltrates consistent with alveolar consolidation on chest radiograph involving at least one complete lung segment [2]. Thus, ACS appears as a form of lung injury clinically similar to pneumonia and may progressively result in hypoxaemia, pulmonary hypertension, and acute respiratory distress syndrome (ARDS). ACS contributes significantly to hospitalisation and mortality of SCD patients, whose lifespan is shortened by approximately three decades $[3,4]$. Treatment recommendations include antibiotic therapy, supplemental oxygen, monitoring and treatment of bronchospasm, red blood cell transfusion, and exchange transfusion in case of rapid progression of ACS [5].

Based on a few case reports in patients with ACS, who developed ARDS, an European panel of experts concluded "that iNO improves oxygenation and decreases pulmonary vascular resistance in some patients with ACS" [6]. The physiological rationale includes pulmonary and systemic actions of iNO. In ARDS, iNO causes selective vasodilation of aerated lung regions with consequent improvement of ventilation/perfusion matching, arterial oxygenation [7], and lowering of pulmonary hypertension with higher iNO doses [8]. The result could be an increase of haemoglobin saturation and reduction of erythrocyte sickling. In patients with $\mathrm{SCD}$, iNO has a number of additional potential mechanisms of action. First, it is expected to inactivate cell-free haemoglobin, thus reducing SCD severity by increasing pulmonary and systemic endogenous NO bioavailability. Second, ACS is associated with an increase in pulmonary arterial pressure (PAP). Echocardiographic measurements performed before and during severe ACS episodes revealed an increase in systolic PAP from 26 to $51 \mathrm{mmHg}$ [9]. High 
iNO concentrations in the order of $80 \mathrm{ppm}$ are expected to induce a considerable reduction in such high PAP values. Finally, iNO may reduce erythrocyte adhesion in the lungs [2].

In a current article in Intensive Care Medicine, Maitre et al. present results from a first prospective, double-blind, randomised, placebo-controlled clinical trial investigating the effects of $80 \mathrm{ppm}$ iNO $(n=50)$ versus placebo $(n=50)$ in SCD patients with ACS. The primary endpoint was treatment failure at day 3 , defined as at least of one of (1) death from any cause, (2) need for endotracheal intubation, (3) decrease of $\mathrm{PaO}_{2} / \mathrm{F}_{\mathrm{I}} \mathrm{O}_{2} \geq 15 \mathrm{mmHg}$ between days 1 and 3, or (4) augmentation of therapy by phlebotomy or transfusion [10]. Disappointingly, the authors found no significant advantage of the iNO treatment. This seems to parallel the recently reported failure of iNO to reduce the severity of pain in $n=150$ patients with sickle cell pain crisis [11]. More closely considered, however, Maitre et al. found a nominal advantage of iNO treatment with respect to the frequency of treatment failure (46 vs. $58 \%$ in controls), which they were not powered to detect. Instead of repeating the investigation with a considerably greater sample size, it is worthwhile to identify possible subgroups with larger effect sizes. Accordingly, in a post hoc analysis, Maitre et al. found a significant benefit of iNO in hypoxemic ACS patients, in whom iNO led to a treatment failure rate $(33 \%)$ less than half that of placebo $(72 \%)$. In contrast, non-hypoxemic ACS patients showed treatment failures in $60 \%$ of the patients receiving iNO versus $44 \%$ in controls, demonstrating a complete lack of positive treatment effect in this second subgroup. The conclusion of Maitre et al. that future controlled clinical trials investigating iNO application in ACS patients should be targeted specifically on severely ill hypoxemic patients is, therefore, entirely justified. Adequately powered, these studies have a promising perspective to prospectively confirm the reported subgroup effects.

Why was iNO effective in hypoxemic ACS patients while non-hypoxemic patients seemingly did not respond to this treatment? In the non-hypoxemic patients in the study by Maitre et al., the median $\mathrm{PaO}_{2} / \mathrm{F}_{\mathrm{I}} \mathrm{O}_{2}$ values can be estimated to be in the order of $400 \mathrm{mmHg}$. These values indicate no serious impairment in gas exchange, and, therefore, an oxygenation benefit of iNO would not be expected. Conversely, the hypoxemic group had median baseline $\mathrm{PaO}_{2} / \mathrm{F}_{\mathrm{I}} \mathrm{O}_{2}$ values of about $230 \mathrm{mmHg}$, suggesting a considerable degree of right-to-left shunt or ventilation/perfusion mismatch, conditions in which iNO is expected to redirect blood flow from non-ventilated to aerated lung regions. A resulting improvement in arterial oxygenation is suggested by the tendency to a lower frequency of deterioration in $\mathrm{PaO}_{2} / \mathrm{F}_{\mathrm{I}} \mathrm{O}_{2}$ by day 3 in the iNO group (9.5 vs. $28 \%$ in controls, $P=0.15$ ). Of note, the data on $\mathrm{PaO}_{2} / \mathrm{F}_{\mathrm{I}} \mathrm{O}_{2}$ in their study were particularly prone to noise, because they used an estimated rather than measured $\mathrm{F}_{\mathrm{I}} \mathrm{O}_{2}$. Among hypoxemic patients, there is also indirect evidence for a better oxygenation in the iNO group from a significantly reduced percentage of patients who received transfusions or phlebotomies when compared to hypoxemic controls. The transfusion triggers given in the supplementary material included alternatively respiratory distress with a respiratory rate $>30 / \mathrm{min}$, pulmonary infiltrates in four quadrants on chest X-ray, and $\mathrm{PaO}_{2} / \mathrm{F}_{\mathrm{I}} \mathrm{O}_{2}$ less than $300 \mathrm{mmHg}$. Thus, an improved oxygenation in the iNO group of the hypoxemic ACS patients might have been the leading cause reducing the need for transfusions and phlebotomies. Additionally, the high iNO concentrations of $80 \mathrm{ppm}$ applied by Maitre et al. might have led to a relief of the pulmonary hypertension commonly seen in the most severe forms of ACS, which might have contributed to the resolution of the ACS.

Future studies concerning the application of iNO in patients with severe ACS should focus on hypoxemic patients, those more likely to benefit. Additionally, it seems important to consider not only the impact on clinical outcomes but also the effects of iNO on arterial oxygenation and pulmonary artery pressure. This information would be of utmost importance to understand the possible modes of action of iNO and to help to identify subgroups of patients who benefit the most. Although this information is still missing, the data presented by Maitre et al. suggest a potential advantage of high iNO doses for adjunctive treatment in patients with severe ACS.

\section{Compliance with ethical standards}

Funding There was no funding.

Conflicts of interest On behalf of all authors, the corresponding author states that there is no conflict of interest.

\section{References}

1. Rees DC, Williams TN, Gladwin MT (2010) Sickle-cell disease. Lancet 376(9757):2018-2031

2. Gladwin MT, Vichinsky E (2008)

Pulmonary complications of sickle cell disease. N Engl J Med

359(21):2254-2265
3. Sheth S, Licursi M, Bhatia M (2013) Sickle cell disease: time for a closer look at treatment options? Br J Haematol 162(4):455-464
4. Kochanek KD, Xu J, Murphy SL, Miniño AM, Kung HC (2011) Deaths: preliminary data for 2009. Natl Vital Stat Rep 59(4):1-51 
5. Yawn BP, Buchanan GR, AfenyiAnnan AN, Ballas SK, Hassell KL, James AH, Jordan L, Lanzkron SM, Lottenberg R, Savage WJ, Tanabe PJ, Ware RE, Murad MH, Goldsmith JC, Ortiz E, Fulwood R, Horton A, JohnSowah J (2014) Management of sickle cell disease: summary of the 2014 evidence-based report by expert panel members. JAMA 312(10):1033-1048

6. Germann P, Braschi A, Della Rocca G, Dinh-Xuan AT, Falke K, Frostell C, Gustafsson LE, Hervé P, Jolliet P, Kaisers U, Litvan H, Macrae DJ, Maggiorini M, Marczin N, Mueller B, Payen D, Ranucci M, Schranz D, Zimmermann R, Ullrich R (2005) Inhaled nitric oxide therapy in adults: European expert recommendations. Intensiv Care Med 31(8):1029-1041
7. Rossaint R, Falke KJ, López F, Slama K, Pison U, Zapol WM (1993) Inhaled nitric oxide for the adult respiratory distress syndrome. N Engl J Med 328(6):399-405

8. Gerlach H, Rossaint R, Pappert D, Falke KJ (1993) Time-course and doseresponse of nitric oxide inhalation for systemic oxygenation and pulmonary hypertension in patients with adult respiratory distress syndrome. Eur $\mathbf{J}$ Clin Invest 23(8):499-502

9. Mekontso Dessap A, Leon R, Habibi A, Nzouakou R, Roudot-Thoraval F, Adnot S, Godeau B, Galacteros F, Brun-Buisson C, Brochard L, Maitre B (2008) Pulmonary hypertension and cor pulmonale during severe acute chest syndrome in sickle cell disease. Am J Respir Crit Care Med 177(6):646-653
10. Maitre B, Djibre M, Katsahian S, Habibi A, Stankovic Stojanovic K, Khellaf M, Bourgeon I, Lionnet F, Charles-Nelson A, Brochard L, Lemaire F, Galacteros F, Brun-Buisson C, Fartoukh M, Mekontso Dessap A (2015) Inhaled nitric oxide for acute chest syndrome in adult sickle cell patients: a randomized controlled study. Intensive Care Med. doi: 10.1007/s00134-015-4060-2

11. Gladwin MT, Kato GJ, Weiner D, Onyekwere OC, Dampier C, Hsu L, Hagar RW, Howard T, Nuss R, Okam MM, Tremonti CK, Berman B, Villella A, Krishnamurti L, Lanzkron S, Castro O, Gordeuk VR, Coles WA, PetersLawrence M, Nichols J, Hall MK, Hildesheim M, Blackwelder WC, Baldassarre J, Casella JF, Investigators DeNOVO (2011) Nitric oxide for inhalation in the acute treatment of sickle cell pain crisis: a randomized controlled trial. JAMA 305(9):893-902 